\title{
Effect of silica nano particles on the rheological and HTHP filtration properties of environment friendly additive in water-based drilling fluid
}

\author{
Ved Prakash $^{1,2}$ D $\cdot$ Neetu Sharma ${ }^{1} \cdot$ Munmun Bhattacharya ${ }^{2}$
}

Received: 4 July 2021 / Accepted: 15 September 2021 / Published online: 27 September 2021

(c) The Author(s) 2021

\begin{abstract}
Rheological and filtration properties of drilling fluid contribute a vital role in successful drilling operations. Rheological parameters such as apparent viscosity (AV), plastic viscosity (PV), yield point (YP) and gel strength of drilling fluids are very essential for hydraulic calculations and lifting of drill cuttings during the drilling operation. Control of filtration loss volume is also very important for cost effective and successful drilling operations. Therefore, the main goal of this research is to improve the rheological and filtration properties of Grewia Optiva fibre powder (GOFP) by using 30-50 nm size of silica nano particles (SNP) in water-based drilling fluid. The experimental outcomes revealed that after hot rolling of mud samples at $100{ }^{\circ} \mathrm{C}$ for $16 \mathrm{~h}$, the low pressure-low temperature (LPLT) and high pressure-high temperature (HPHT) filtration loss of GOFP additives was improved, after the addition of SNP on it. The mixture of 5\% GOFP $+4 \%$ SNP has reduced the LPLT and HPHT filtration loss of drilling fluid by 74.03 and $78.12 \%$, respectively, as compared to base mud. Thus, it was concluded that after the addition of $0.4 \%$ SNP, the LPLT and HPHT filtration control ability of GOFP additive in WBM were increased by 17.6 and $15 \%$, respectively. The rheological parameters such as AV, PV, YP and gelation of drilling fluids were also improved by the addition of GOFP + SNP mixture in the base mud. Therefore, the implementation of GOFP + SNP mixture in water-based mud showed auspicious results which reaffirm the feasibility of using them in the successful drilling operations.
\end{abstract}

Keywords Drilling fluid $\cdot$ Grewia Optiva fibre $\cdot$ HPHT filtration property $\cdot$ Rheology $\cdot$ Silica nano particles

\section{Introduction}

Drilling in deeper wells is very challenging and costly due to high pressure and high temperature (HPHT) conditions (Caenn and Darley 2017a). Water-based mud (WBM) has a number of advantages over the oil-based drilling fluid (ODF), including low cost, easily available, superior cooling, cutting removal ability, rapid formation penetration rate, and environment friendly nature. Water acts as dispersion medium in the WBM due to the presence of the excess

Ved Prakash

vedprakashdhyani28@gmail.com

1 Department of Chemistry, Graphic Era Deemed to be University, Dehradun, Uttarakhand, India

2 Department of Drilling Fluid Engineering (R \& D), Institute of Drilling Technology (IDT), Oil and Natural Gas Corporation Limited (ONGC), Dehradun, Uttarakhand, India amount; as a result, the filtrate generated due to temperature and pressure during the drilling enter in the porous rock formations and causes swelling of shale, caving, stuck up, bore hole instability and formation damage problems (Caenn and Darley 2017b; Fink et al. 2012). Beyond the temperature 250 ${ }^{\circ} \mathrm{F}$, bentonite starts deteriorating, which leads to decrease in viscosity and increase the filtration loss volume of drilling fluid (Caenn and Darley 2017a). To design a suitable and efficient drilling fluid, the rheological and filtration properties are the key parameters (Caenn and Darley 2017c, d). Hot rolling of drilling fluids in roller oven at particular temperature is very essential because it correlate the behaviour of drilling mud when drilling is resumed in the well bore. Drilling fluid samples are kept in a stainless-steel ageing cell and rolled inside the hot roller oven at a particular temperature for minimum of $16 \mathrm{~h}$ to predict the effect of temperature on parameters of the drilling fluid after the long hot rolling (Liu et al. 2016). 
Recently, various polymeric additives like polyanionic cellulose (PAC) (Kafashi et al. 2017; Villada et al. 2017), hydroxyethyl cellulose (HEC) (Chaouf et al. 2019; Lian et al. 2019), carboxymethyl cellulose (Menezes et al. 2010; Zhang et al. 2016), acrylamide-styrene copolymer (SBASC) (Davoodi et al. 2019), Partially hydrolysed polyacrylamide (PHPA) (Jain et al. 2015), polyethylene glycol (Mech and Sangwai 2016), low and high density polythene (Yi et al.2017), etc. have been used in water-based drilling fluid to ameliorate the rheological and filtration properties of the drilling fluids. While polyacrylamide (Magzoub 2021) has been used as lost circulation material in WBM. But, in deeper wells, these polymers are deteriorated at high temperature after a period of time. Therefore, various nanoparticles are used in drilling fluid for improving its performance (Zakaria et al. 2012; Abbas et al. 2021; Akhtarmanesh et al. 2013).

Nano particles are surface-charged particles, which have been used widely in the drilling fluid since last couple of decades to improve the efficacy of drilling fluid at high temperature as compared to polymeric additive (Aftab et al. 2017; Rafati et al. 2018). The heat stability, filtration and rheological properties of drilling fluid have been improved by nano particles in water-based drilling fluid; therefore, suitable size of nano particle is the explication of drilling under the drastic conditions like HPHT and water-sensitive shale formations.(Cheraghian et al. 2021. Hoelscher et al. 2012, Katenda et al. 2019). Recently, various nano particles like bismuth ferrite (Perween et al. 2019), hydrophilic gilsonite (Pakdaman et al. 2019), cupric oxide and zinc oxide (Beg et al. 2019; Dejtaradon 2019), zinc titanate (Perween et al. 2018) and magnesium aluminium silicate (Wang et al. 2018), barite nano particle (Caldarola, 2016. Loggins et al. 2017) titanium dioxide (Bayat et al. 2019), $\mathrm{TiO}_{2} /$ Polyacrylamide nanocomposite (Sadeghalvaad et al. 2015), etc. as additives have been used in water-based drilling fluid to improve its efficiency. Cellulose nanoparticles (CNPs), microfibrial cellulose (MFC) and cellulose nanocrystal have been improved the rheological and filtration property of bentonite-based drilling fluid ( $\mathrm{Li}$ et al. 2015). The salt contamination of bentonite water-based drilling fluid with cellulose nanocrystal reveal that cellulose nanocrystal stabilized rheology and filtration property of bentonite waterbased mud (Li et al. 2020a, b, c). Water-based drilling fluids (WDFs) with thermo controllable rheological properties are developed using bentonite (BT) and dual-functionalized cellulose nanocrystals (fCNCs). This work demonstrated a new concept of formulating smart drilling fluid based on $\mathrm{BT}$ and biomass-derived CNCs via rational surface fictionalization and interface design, paving the way for the development of next generation of drilling fluids with low toxicity, sustainability, in situ rheology controllability, and thermal tolerance. (Li et al. 2020a,b, c). Cellulose nanofibres
(CNFs) and polyanionic cellulose (PAC) hybrid have been used as rheological and filtration loss modifiers in the high performance water-based mud. The outcomes of this study revealed that CNFs andPAC hybrid potentially improved the rheological and filtration property of bentonite-based drilling fluid ( $\mathrm{Li}$ et al. 2020a, b, c). Silica nano particle with xanthan gum has been used for enhancing rheological, filtration and lubrication properties of a water-based drilling fluid system (Al- Yasiri et al. 2019). Clay/SiO2 nanocomposite was synthesized and analysed by conventional characterization methods. This novel system of drilling fluid containing nanoparticles has shown improvement in rheological properties as well as filtration control. It has been found that the clay/silica nanocomposites have a tendency to improve the rheological stability of drilling mud at higher temperature (Cheraghian et al. 2018). A novel hydrophobic associated polymer-based silica nanoparticles composite with core-shell structure has been provided the thermal stability of water-based mud system. It has improved the rheology, lubricity and filtration properties of water-based mud system. The HPHT filtration loss at $200^{\circ} \mathrm{C} / 16 \mathrm{~h}$ with silica nanoparticle was $20.5 \mathrm{ml}$ (Mao et al. 2015). Silica and grapheme nanoparticles used in water-based mud system to improve the shale stability during the drilling operations. These nanoparticle reduced the Woodford shale cutting dispersion by $35.61 \%$ as compared to base fluid, which showing its effectiveness in water-based drilling fluid in illitic shales (Aramendiz, et al. 2019). In another study, it was observed that with varying the concentration of silica nano particles from 0.001 to $1.5 \mathrm{wt} \%$ in the WBM, the viscosity of drilling mud was increased (Gbadamosi et al. 2019).

In the recent years, several natural products have been studied in water-based drilling fluid. These additives are Corncorb and sugar cane as viscosifying agent (Iranwan et al. 2009), Banana peel ash as pH enhancer (Adebowale and Raji 2015), However, rice husk (Okon et al. 2014), extracted cashew and mango leaves (Omotioma et al. 2014), extracted potato starch from potato tubers (Nyeche et al. 2015),grass (Hossain and Wajheeuddin 2016), date seed powder (Amanullahand Ramasamy 2016), corn cob and coconut shell (Onuh et al. 2017), rice husk and saw dust (Agwu, Okorie. et al. 2019), potato peels powder(AlHameedi 2019), etc. all these additives have been used as filtration loss control agent in the water-based mud. Various lost circulation materials (LCM's) have been used in water-based drilling fluid to stop losses (Alsaba et al. 2014). Recently, used LCM in WBM is Durian rind (Fatihah Majid 2019). Beyond these, other additives like, pomelo peels powder as effective shale inhibitor (Zhang et al. 2020), and stem peels powder of Grewia Optiva fibres (particle size $250 \mu \mathrm{m}$ ) as non-invasive fluid additive (Prakash et al. 2020), etc. have been studied in water-based drilling fluid. 
Above references are suggesting for the use of nano particles with natural additive in WBM so that the performance of natural product may be improved at high temperature and high pressure conditions. Therefore, in the present work, $30-50 \mathrm{~nm}$ size of silica nano particles (99.9\% purity) are used with the natural product Grewia optiva fibre (particle size125 $\mu \mathrm{m}$ ) to improve the rheology, LPLT and HPHT filtration properties of WBM.

Grewia Optiva is an agro- forestry tree. It is commonly known as Bhimal. It is a tree of about $12 \mathrm{~m}$ height, and found in India, Srilanka, Pakistan, Thailand, China and Phillipines. Leaves are ovate and lanceolate, acuminate, base rounded with prominent nerves, margin serrate, and stallately hairy on both surfaces. The fibre is used in the manufacturing of ropes, nets, brooms and sticks. The advantage of this fibre over the other natural products is its tensile strength and thermal stability (Gaur et al. 1999). Raw grewia optiva fibre contained $68.9 \pm 1.5 \%(\mathrm{w} / \mathrm{w})$ cellulose, $16.8 \pm 0.5 \%(\mathrm{w} / \mathrm{w})$ hemicelluloses, $12.8 \pm 1.5 \%(\mathrm{w} / \mathrm{w})$ legnin and $1.5 \pm 0.5 \%(\mathrm{w} / \mathrm{w})$ pectin and wax (Karakoti et al. 2020), which motivated the use of Grewia optiva fibre with silica nano particles in the water-based mud.

\section{Materials and methods}

Materials used for the study are bentonite powder (Provided by Oil and Natural Gas Corporation Limited, Dehradun, India), soda ash (manufactured by Central drug house pvt. Ltd. New Delhi, India), caustic soda (manufactured by RFCL limited new Delhi, India), Grewia Optiva fibre (collected from Himalayan region of Garhwal Uttarakhand,India) and silica nano particles with $30-50 \mathrm{~nm}$ size and $99.9 \%$ purity were purchased from the Parshwamani metals Pvt. Limited, Mumbai, India.

\section{Sample preparation of grewia optiva fibre powder (GOFP)}

Raw fibre was obtained from the branches of the Grewia Optiva, were collected during the month of November from the Garhwal region of Uttarakhand, India. These branches were first wetted with water for 3-4 weeks and then fibrous peels were separated from the sticks by dissolving gummy material. The fibrous peels thus obtained were thoroughly rinsed with $2 \%$ detergent solution and then placed in a dry oven at $70{ }^{\circ} \mathrm{C}$ for $24 \mathrm{~h}$ (Prakash et al. 2020). When these fibrous peels were completely oxidized, they were cooled and further cut into small pieces with the help of a sharp knife. Ground these fibrous peels (Fig. 1 a) into fine powder through a grinder machine and sieved to $125(\mu \mathrm{m})$ (Fig. 1 b). The reason for using $125 \mu \mathrm{m}$ particle size additive is to increase surface area and the area of extent for effective ability of any natural product to be a better filtration loss control additive (Ghazali et al. 2014).

\section{Experimental procedures and laboratory measurements}

\section{Mud samples preparation}

A fresh bentonite mud was prepared as per API (American Petroleum Institute) standards. About 7\% Bentonite, $0.1 \%$ soda ash and $0.2 \%$ caustic soda were mixed in $350 \mathrm{ml}$ of water, and the resulting mixture was kept at room temperature for $24 \mathrm{~h}$ (Table 1). Here, this mud was designated as base mud. Followed by it, four another mud samples were

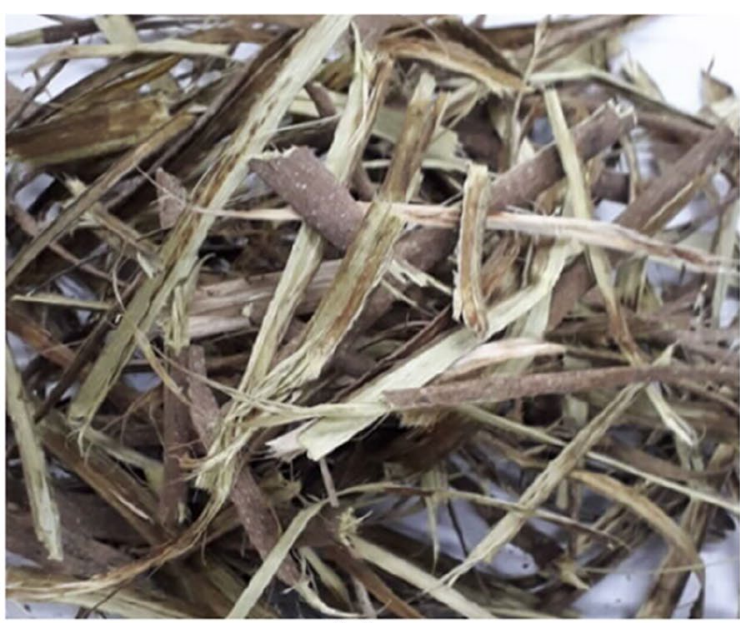

(a)

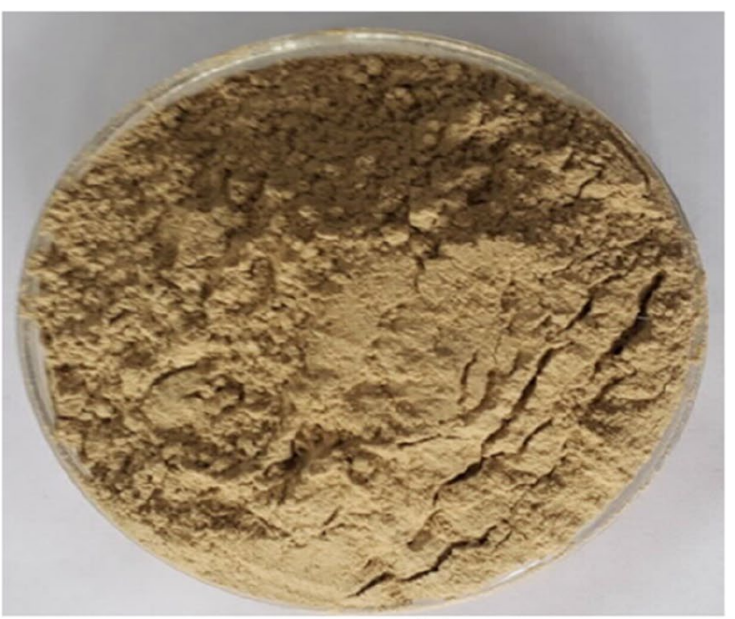

(b)

Fig. 1 a Raw fibre of Grewia Optiva, b $125 \mu \mathrm{m}$ Grewia Optiva fibre powder (GOFP) 
Table 1 Materials used for the mud formulation

\begin{tabular}{llll}
\hline Mud material & Conc. \% (w/v) & $\begin{array}{l}\text { Mixing } \\
\text { time (sec- } \\
\text { ond) }\end{array}$ & $\begin{array}{l}\text { Function of } \\
\text { materials }\end{array}$ \\
\hline Water & $500 \mathrm{ml}$ & - & Base liquid \\
Bentonite & 7 & 900 & $\begin{array}{l}\text { Viscosifier } \\
\text { Soda ash }\end{array}$ \\
$\begin{array}{l}\text { Caustic soda } \\
\text { GOFP }\end{array}$ & 0.1 & 200 & $\begin{array}{l}\text { Softness of water } \\
\text { pH enhancer }\end{array}$ \\
$\begin{array}{l}\text { Silica nano Par- } \\
\text { ticles }\end{array}$ & $0.2-0.4$ & 300 & $\begin{array}{l}\text { Fluid loss control } \\
\text { agent } \\
\end{array}$ \\
\end{tabular}

also prepared. Out of these four mud samples, first sample contain 5\% GOFP in base mud which was designated as GOFP-based mud. While second, third and fourth mud samples contain $5 \%$ GOFP $+0.2 \%$ SNP, $5 \%$ GOFP $+0.3 \%$ SNP, $5 \%$ GOFP $+0.4 \%$ SNP, respectively, in the base mud, which were designated as SNP-based drilling fluid. All these mud samples were mixed thoroughly in the Hamilton beach mixer at $1800 \mathrm{rpm}$ for $30 \mathrm{~min}$ to obtain homogenous mixture. Upreti et al. (2017) also showed that at $5 \mathrm{wt} \%$ concentration, the tensile strength of Grewia optiva fibre was very high, while when the concentration of this fibre was increased to beyond 5\%, its tensile strength began to decompose due to decrease in bonding between the fibre and matrix. Thereafter, the low pressure-low temperature (LPLT) filtration test, rheological properties and mud cake thickness, mud cake permeability, $\mathrm{pH}$, and density test of all mud samples were performed (Table 2). After evaluating the required parameters, all mud samples were now put in ageing cells and hot rolled at $100{ }^{\circ} \mathrm{C}$ for $16 \mathrm{~h}$. After hot rolling of mud samples, the various parameters of drilling fluids such as LPLT and HPHT filtration test and rheology, etc. were determined (Table 3 ).

\section{Rheological properties measurements}

Fann viscometer model 35 was used to measure the rheological parameters of drilling fluid. A steady dial reading is noted at different RPM in viscometer to determine the apparent viscosity, plastic viscosity, yield point, and gel strength of the drilling fluid. The gel strength at $10 \mathrm{~s}$ and $10 \mathrm{~min}$ was determined at $3 \mathrm{rpm}$. Formulae: Rheological properties such as AV (Eq. 1), PV (Eq. 2) and YP (Eq. 3) of drilling mud are calculated by the following equations:

$A V=\theta_{600} / 2$

$P V=\theta_{600}-\theta_{300}$

$Y P=\theta 300-P V$

where $\theta_{600}=$ Dial reading at $600 \mathrm{RPM}, \Theta_{300}=$ Dial reading at $300 \mathrm{RPM}$

\section{LPLT (low pressure-low temperature) filtration test}

Mud was filled in a cell containing a Whatman 50 filter paper with a diameter $90 \mathrm{~mm}$ at bottom along with a filter screen. After the necessary connections, a 100 Psi pressure at room temperature was exerted on drilling mud by using nitrogen gas for a period of $30 \mathrm{~min}$ (American Petroleum Institute 2003).

\section{HPHT (high Pressure-high temperature) filtration test}

Ofite 171-00 series HPHT filter press was used to determine the HPHT filtration loss of drilling fluids. Mud was filled in the in the HPHT filter press cell containing filter paper with diameter of 2.5 inch. When mud acquired required temperature, 500 psi differential pressure (600 psi from the top of cell and 100 psi from the bottom of cell) was applied in the
Table 2 Properties of SET-1, SET-2 and SET-3 mud samples at before hot rolling (BHR)

\begin{tabular}{|c|c|c|c|c|c|}
\hline \multirow[t]{2}{*}{ Mud properties } & \multicolumn{5}{|l|}{ Values } \\
\hline & Base mud & $5 \%$ GOFP & $\begin{array}{l}5 \% \\
\text { GOFP }+0.2 \% \\
\text { SNP }\end{array}$ & $\begin{array}{l}5 \% \\
\text { GOFP }+0.3 \% \\
\text { SNP }\end{array}$ & $\begin{array}{l}5 \% \\
\text { GOFP }+0.4 \% \\
\text { SNP }\end{array}$ \\
\hline Mud weight (ppg) & 8.68 & 8.70 & 8.70 & 8.70 & 8.70 \\
\hline $\mathrm{pH}$ & 10.5 & 10.3 & 10.0 & 9.8 & 9.7 \\
\hline $\mathrm{AV}(\mathrm{cP})$ & 18 & 31 & 34 & 36 & 38 \\
\hline $\mathrm{PV}(\mathrm{cP})$ & 10 & 15 & 16 & 17 & 18 \\
\hline $\mathrm{YP}\left(\mathrm{lb} / 100 \mathrm{ft}^{2}\right)$ & 22 & 30 & 34 & 36 & 38 \\
\hline Gel $0\left(\mathrm{lb} / 100 \mathrm{ft}^{2}\right)$ & 18 & 23 & 23 & 24 & 26 \\
\hline Gel $10\left(\mathrm{lb} / 100 \mathrm{ft}^{2}\right)$ & 27 & 34 & 38 & 40 & 42 \\
\hline LPLT, Filtration loss volume (cc) & 27 & 6.4 & 6.1 & 5.7 & 5.3 \\
\hline Filter cake thickness (mm) & 3.0 & 1.8 & 1.8 & 1.7 & 1.6 \\
\hline
\end{tabular}


Table 3 Properties of SET-1, SET-2 and SET-3 mud samples, After Hot Rolling (AHR) at 100 ${ }^{\circ} \mathrm{C}$ for $16 \mathrm{~h}$

\begin{tabular}{llllll}
\hline Mud properties & \multicolumn{2}{l}{ Values } & & \\
\cline { 2 - 6 } & Base mud & $5 \%$ GOFP & $5 \%$ & $5 \%$ & $5 \%$ \\
& & & GOFP+0.2\% & GOFP+0.3\% & GOFP+0.4\% \\
& & & SNP & SNP & SNP \\
\hline Mud weight (ppg) & 8.68 & 8.7 & 8.7 & 8.7 & 8.7 \\
pH & 9.5 & 9.0 & 9.0 & 8.8 & 8.6 \\
AV(cP) & 14 & 24 & 26 & 28 & 30 \\
PV (cP) & 7 & 11 & 11 & 12 & 14 \\
YP (lb/100ft ${ }^{2}$ ) & 16 & 23 & 25 & 28 & 30 \\
Gel 0 (lb/100ft ${ }^{2}$ ) & 11 & 19 & 20 & 21 & 23 \\
Gel 10(lb/100ft ${ }^{2}$ ) & 19 & 25 & 26 & 30 & 34 \\
LPLT, Filtration loss volume (cc) & 32 & 8.5 & 8.0 & 7.3 & 7.0 \\
LPLT, Filter cake thickness (mm) & 3.5 & 2.0 & 2.0 & 1.8 & 1.8 \\
HTHP, Filtration loss volume (cc) & 52 & 16 & 15.2 & 14.2 & 13.6 \\
HPHT, Filter cake thickness (mm) & 7.7 & 5.0 & 4.6 & 4.3 & 4.2 \\
\hline
\end{tabular}

HTHP filter press. After 30 min, the final volume of filtrate collected in a measuring cylinder was noted.

\section{Results}

\section{Zeta Potential and particle size analysis of nano particles}

Zeta potential is one of the most important parameters to estimate the stability of the nanoparticle as it gives the net electrostatic potential of any particle in suspension. Particles having zeta potential value more positive than $+30 \mathrm{mV}$ or more negative than $-30 \mathrm{mV}$ are generally treated as stable. For determining the Zeta potential, $5 \mathrm{mg} / \mathrm{L}$ of silica nano particles solution was prepared, stirred the solution by silverson mixture for $15 \mathrm{~min}$. Maintained the $\mathrm{pH}$ of solution up to 10 by using $0.1 \mathrm{M} \mathrm{NaOH}$ solution. A similar methodology was applied for determining the zeta potential of GOFP and the mixture of GOFP + SNP samples. As per experimental data, it was observed that silica nano particles (SNP) possessed a zeta potential value of $-47.4 \mathrm{mV}$ (Fig. 2a), which clearly indicates that nanoparticles are stables. Nanoparticles having high positive or high negative zeta potential value are never aggregate due to repulsive forces between the particles (Selvarajan et al. 2013). Similarly, the zeta potential of GOFP was $-24.1 \mathrm{mV}$ (Fig. 3a), which indicates moderate stability of particles, while when the particles of GOFP and SNP were mixed, the zeta potential of these mixed particles was found to $-31.1 \mathrm{mV}$ (Fig. 4a), which represents that these particles are stable and prevent aggregation due to repulsive forces among the particles. The average particles size $\left(\mathrm{Z}_{\mathrm{Avg}}\right)$ of GOFP and SNP were found to $246 \mathrm{~nm}$ and $200 \mathrm{~nm}$ respectively (Fig. 2b and $3 b$, respectively). While the $\left(Z_{\mathrm{Avg}}\right)$ value of GOFP $+\mathrm{SNP}$ mixture was $229 \mathrm{~nm}$ (Fig. 4b). The particle size distribution data indicates the agglomeration of nanoparticles in water, this agglomeration formed larger size nanoparticles. As a result, the average size of nano particles was found much larger than the size of nano particles used.

\section{XRD Analysis}

XRD tests of grewia optiva fibre were recorded within the range from 5 to $90^{\circ}$ with an increment of 0.02 and a speed of $5 \% \mathrm{~min}$. The crystallinity index is calculated by using equation (4) (Segal et al. 1959)

Crystallinity index $=I_{002}-I_{\text {amorph }} / I_{002} \times 100$

Where $\mathrm{I}_{002}=$ Intensity of (002) lattice diffraction, $\mathrm{I}_{\text {amorph }}=$ Intensity of diffraction $\left(18^{\circ}\right)$.

Three peaks are identified in the direction of 15.3, 22.5 and $24.4^{\circ}$ and in raw grewia optiva fibre as shown in Fig. 5a. Crystalline index indicated that the crystalline phase of grewia optiva fibre is $60 \%$ and the remaining $40 \%$ is the amorphous phase due to the lignin, hemicellulose and pectin content. This peak is showing higher intensity in the direction of 16.5, 22.7 and $24.8^{\circ}$ in SNP-treated fibbers (Fig. 5b). The crystallinity index is increased from $60 \%$ in the raw fibre to $80 \%$ with silica nano particles which is indicating an improvement in the order of regularity in constituent particles. 

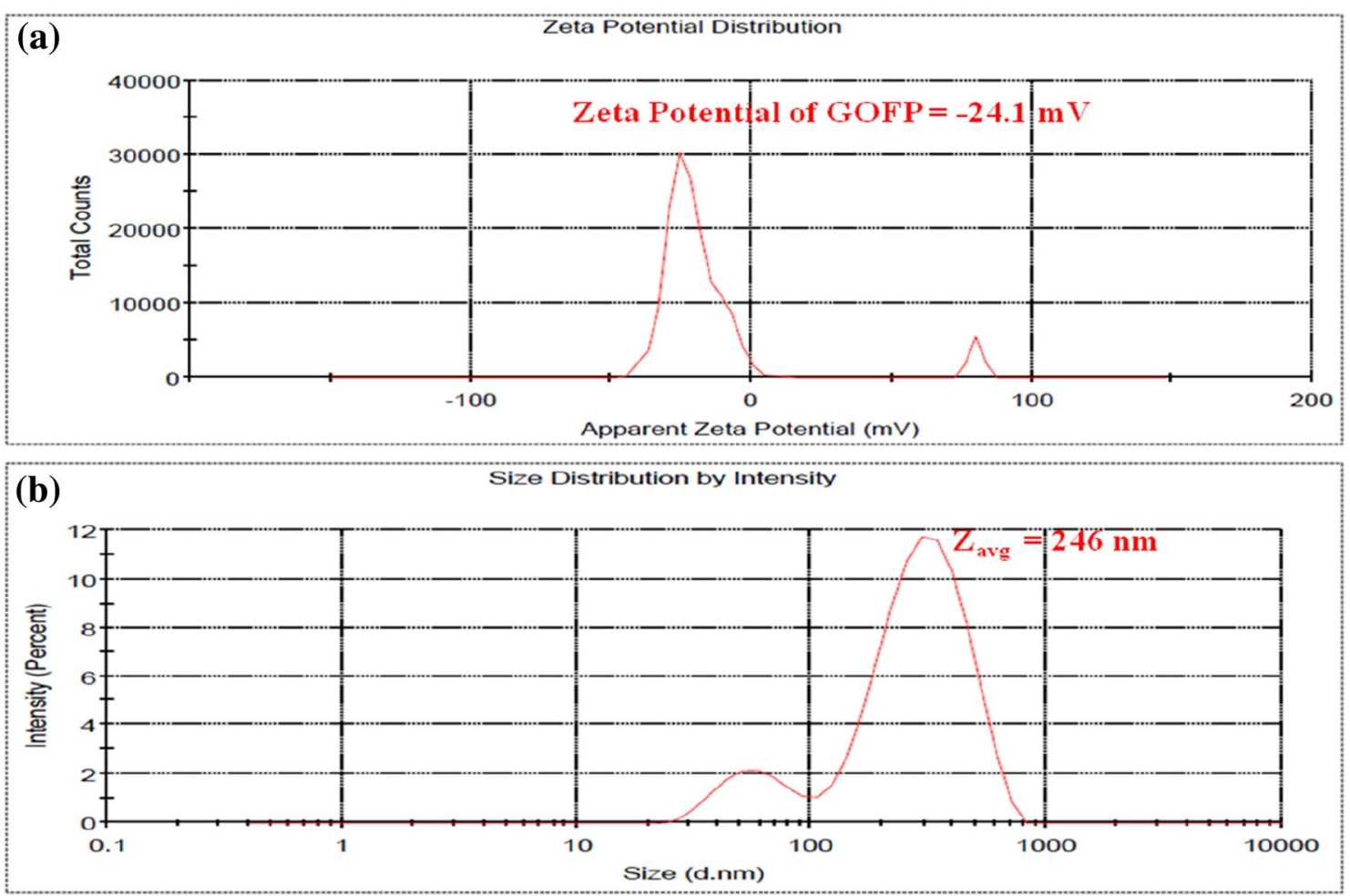

Fig. 2 a Zeta Potential of SNP, b Average particle size of SNP
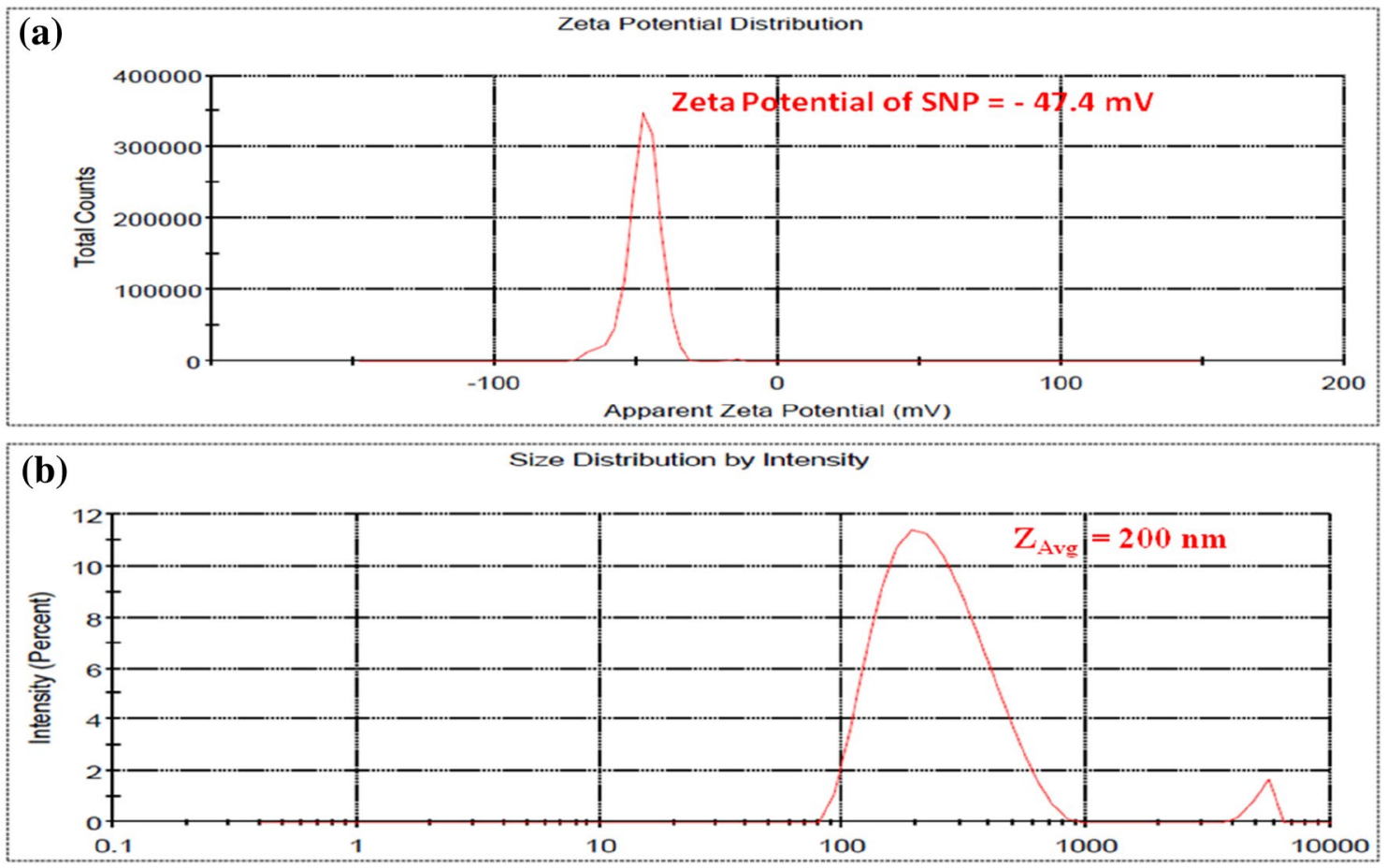

Fig. 3 a Zeta Potential of GOFP, b Average particle size of GOFP 

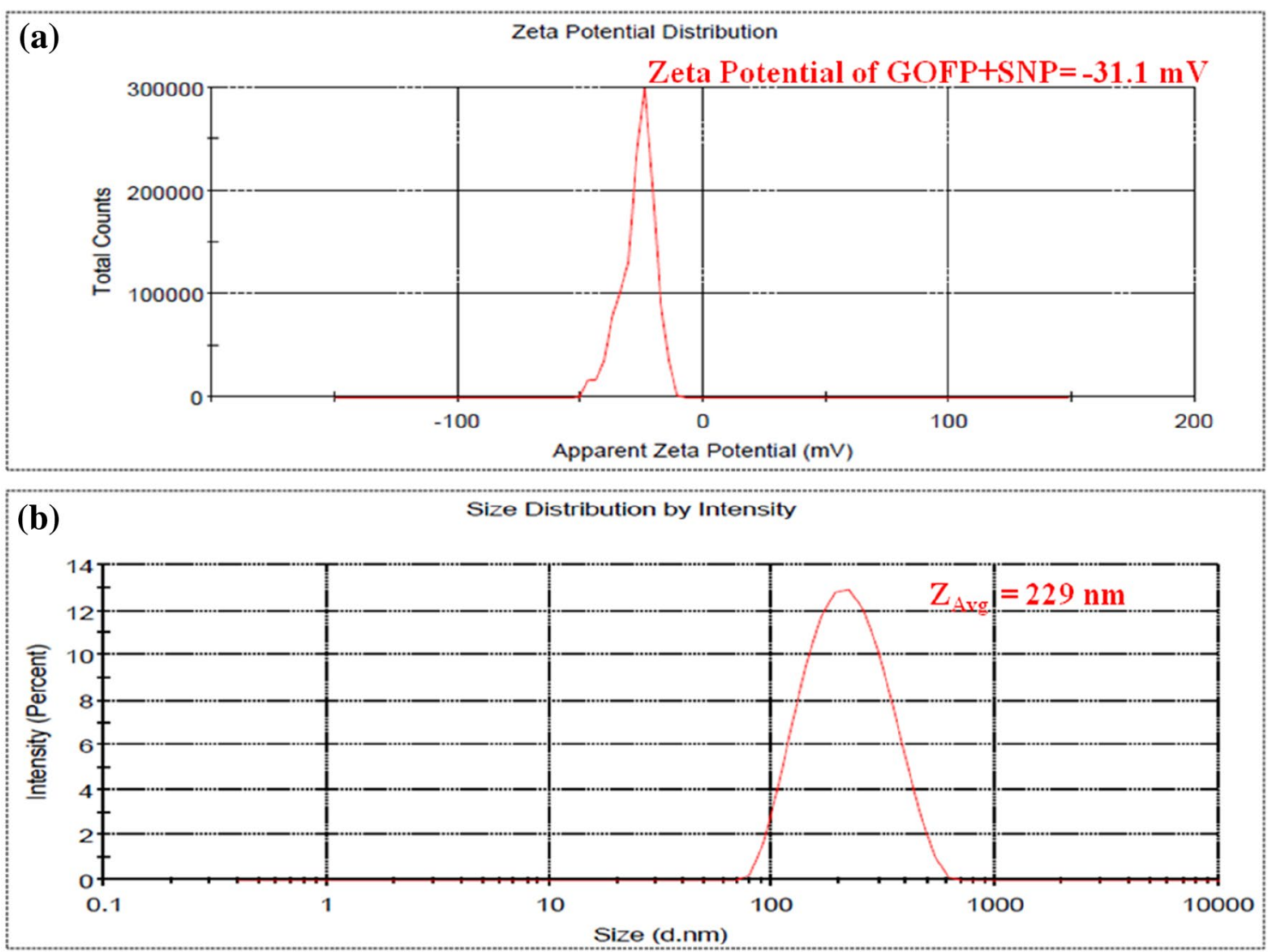

Fig. 4 a Zeta Potential of GOFP + SNP Mix. b Average particle size of GOFP + SNP Mix

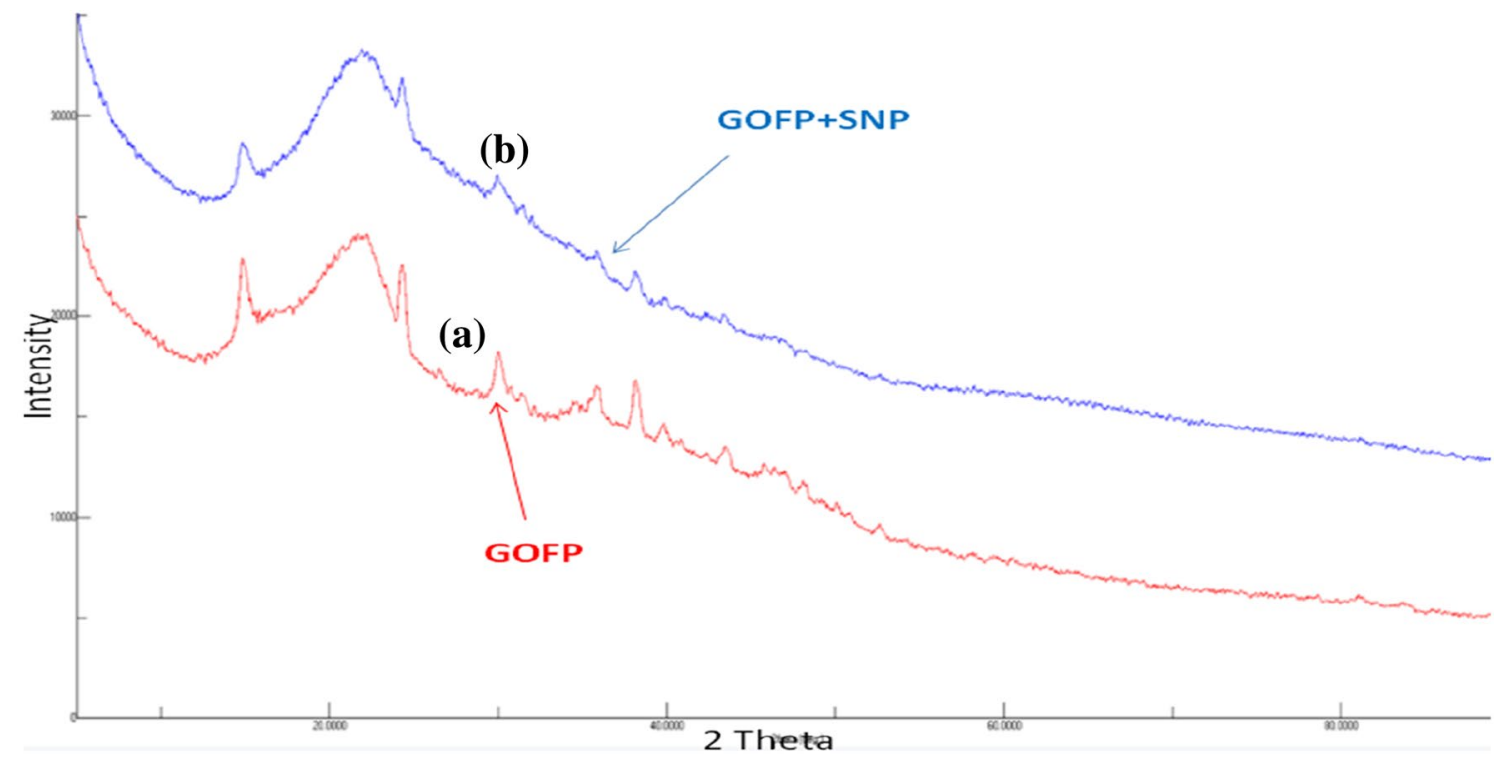

Fig. 5 a XRD graph of GOFP, $\mathbf{b}$ XRD graph of GOFP + 0.4\% SNP particles 


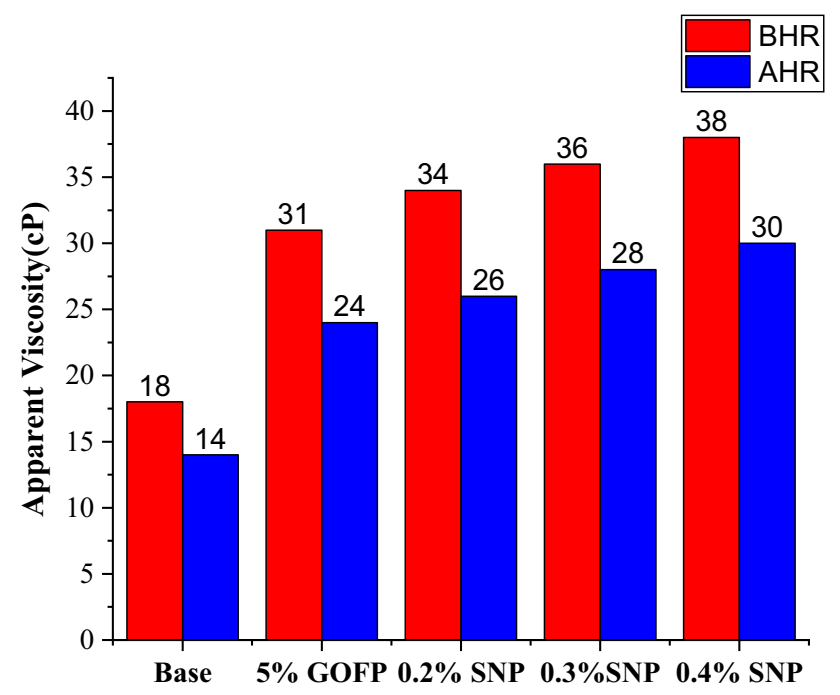

Fig. 6 Effect on apparent viscosity of different drilling fluid samples at BHR and AHR $\left(100{ }^{\circ} \mathrm{C}\right)$

\section{Mud samples analysis}

\section{Discussion}

\section{Effect on the rheological properties of drilling fluids}

\section{Apparent viscosity(AV)}

AV represents the effective viscosity of the fluid, which depends on the ratio of shear stress and shear rate. Before hot rolling (Fig. 6), the AV of base mud and 5\% GOFP mud were $18 \mathrm{cP}$, and $31 \mathrm{cP}$ respectively. While with increasing the concentration of SNP from 0.2 to $0.4 \%(w / v)$ in GOFP mud, the AV of drilling mud was increased significantly from 34 to $38 \mathrm{cP}$ respectively. After hot rolling of mud samples at $100{ }^{\circ} \mathrm{C}$ for $16 \mathrm{~h}$, the $\mathrm{AV}$ of all mud samples were decreased as compared to the AV of drilling muds at before hot rolling (BHR), this is due to the thermal degradation of chemical after long hot rolling. As per experimental data, it was observed that even after long hot rolling, the AV of the drilling mud containing the mixture of 5\% GOFP and $0.4 \%$ SNP was highly stable as comparison to other drilling fluid systems. Thus, we can say that the AV of GOFP base mud was increased drastically by $25 \%$ after the addition of $0.4 \%$ (w/v) SNP on it, which would be stabilized the viscosity of the mud during the drilling.

\section{Plastic viscosity (PV)}

It represents the frictional forces present in the drilling fluids. These frictional forces may be solid to solid, solid to liquid and liquid to liquid itself. PV of the drilling fluid is

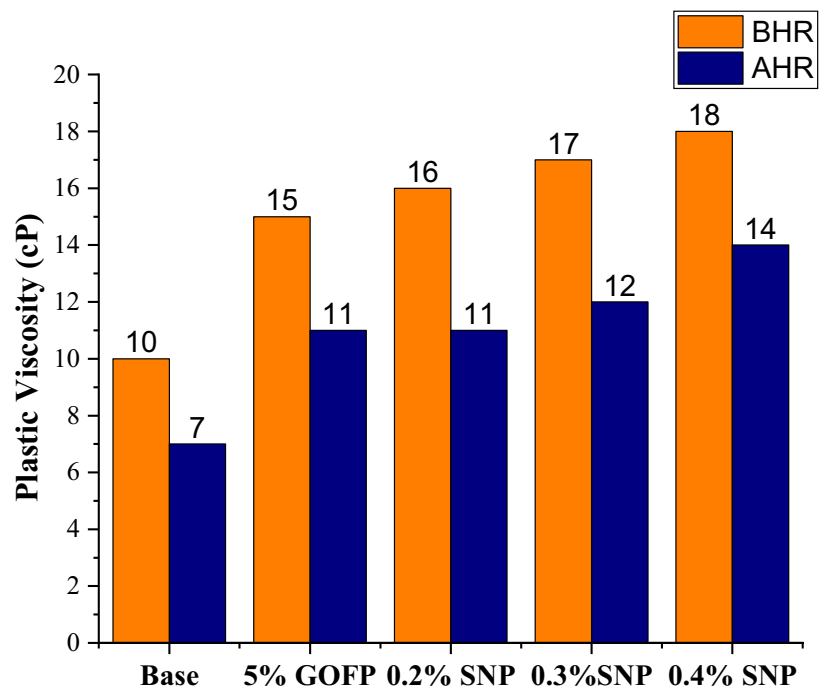

Fig. 7 Effect on plastic viscosity of different drilling fluid samples at BHR and AHR $\left(100^{\circ} \mathrm{C}\right)$

generally increased by the addition of solid particles in the mud sample (Baker 2006). Data represented in Fig. 7 shows that after long hot rolling of various drilling fluid systems, the PV of all drilling fluids were decrease as compared to the before hot rolling, this is due to the thermal degradation of attractive forces among the mud particles. After hot rolling, the PV of base mud was $7 \mathrm{cP}$, while after the addition of $5 \%$ GOFP additive in base mud, the PV of resulting drilling fluid was increased to $11 \mathrm{cP}$. But, there was no change in PV was observed after the addition of $0.2 \% \mathrm{SNP}(\mathrm{w} / \mathrm{v})$ in the mud. However, the PV of mud was increased from 12 and $14 \mathrm{cP}$ with increasing the concentration of SNP from 0.3 to $0.4 \%$,

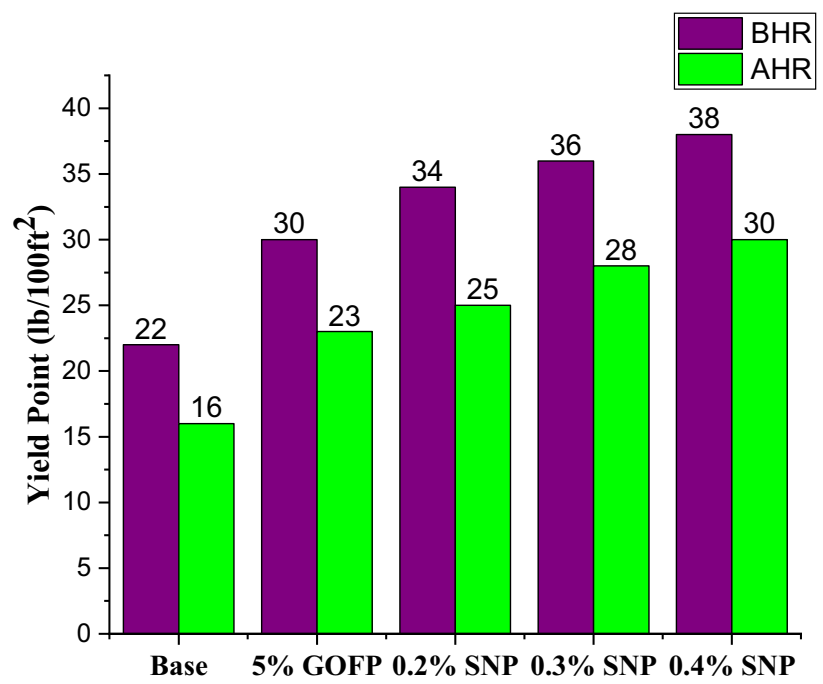

Fig. 8 Effect on yield point of different drilling fluid samples at BHR and AHR $\left(100^{\circ} \mathrm{C}\right)$ 
respectively. Thus, overall results indicate that there is very less enhancement in PV after the addition of silica nano particles from 0.2 to $0.4 \%$ in 5\% GOFP base mud, which is a good advantage of silica nano particles.

\section{Yield point(YP)}

Yield point (YP) of the drilling mud is a physical property that indicates the initial force in pound per sq. inch required to be applied to plastic or pseudo plastic, non-Newtonian fluids, in order to bring it to flowing state and it signifies the hole cleaning efficiency of the drilling fluid. Figure 8 shows that after hot rolling of mud samples for $16 \mathrm{~h}$, the YP of drilling mud was increased by 8.6, 21.7 and 23.3\% after the addition of $0.2,0.3$ and $0.4 \%$ SNP respectively in GOFP based mud. While after the addition of $0.4 \%$ SNP along with 5\% GOFP in the base mud, the YP of resulting mud was increased by $87.5 \%$. This is due to larger surface area and smaller size of SNP, the electrostatic force of attraction among the mud particles is also increased. This modified viscosity of drilling mud obtained after the use of 5\% GOFP $+0.4 \%$ SNP in the base mud would be supported in the lifting of drilling cutting from the bottom hole to the surface during the drilling operations.

\section{Gel strength}

Gel strength of drilling fluid is mainly measured at 3 RPM with time interval of $10 \mathrm{~s}$ and $10 \mathrm{~min}$ by viscometer. It represents the strength of attractive forces in drilling mud under static conditions (Hakim, et al. 2018). The gel 0 and gel 10 value of various drilling fluids are plotted in Fig. 9, which are showing that the gelation of drilling fluids was increased gradually by the addition of GOFP and the various

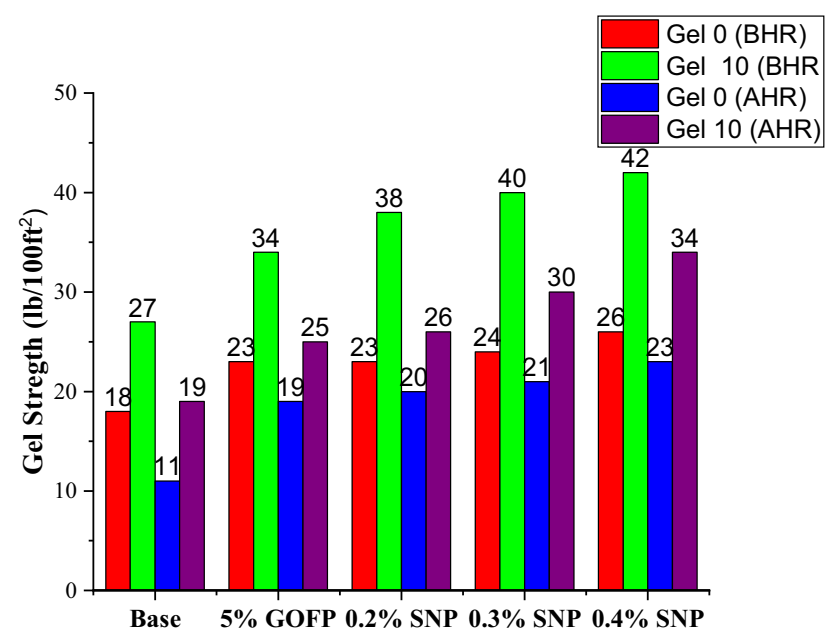

Fig. 9 Effect on Gel Strength of different drilling fluid samples at BHR and AHR $\left(100{ }^{\circ} \mathrm{C}\right)$ concentration of SNP in the base mud. After hot rolling of mud samples, the Gel 0 values of base mud, GOFP mud and $5 \% \mathrm{GOFP}+0.4 \%$ SNP (optimized concentration) mud were 11, 20 and 25 respectively. While the Gel 10 values of these mud samples were 19, 25 and 34 respectively. The Gel 0 and Gel 10 values of SNP-based mud is showing fragile gelation, which is very essential for optimum drilling operation because this gelation ensure that no excess shear stress is required to break the gel again into the fluid when drilling operation would be resumed (Baker 2006). The optimum gelation value of SNP based mud would be helped in the holding of drill cuttings during the static condition.

\section{Effect on the filtration properties of drilling fluid}

\section{LPLT filtration property}

Filtration loss represents the ability of drilling fluid to plug permeable or producing formations by forming low filter cake. It occurs in two ways, i.e., static and dynamic (Hakim, et al. 2018). In the present study, the volume of filtration loss and the thickness of the filter cake was measured in the static conditions. Experimental data presented in Fig. 10 indicate that after hot rolling of mud sample at $100{ }^{\circ} \mathrm{C}$ for $16 \mathrm{~h}$, the LPLT filtration loss volume of the base mud and 5\% GOFP based mud were $32 \mathrm{ml}$ and $8.5 \mathrm{ml}$, respectively. These data indicates that, after the addition of 5\% GOFP in the base mud, the LPLT filtration loss volume was decrease by $73.4 \%$ (from 32 to $8.5 \mathrm{ml}$ ) which is showing better LPLT filtration loss control ability of grewia optiva fibre powder (GOFP) in the water-based drilling. Okon et al. (2014) showed that after addition of $10 \mathrm{gm} \mathrm{CMC}$ in $350 \mathrm{ml}$ of base mud, the LPLT filtration loss volume of drilling mud was reduced by $62.77 \%$

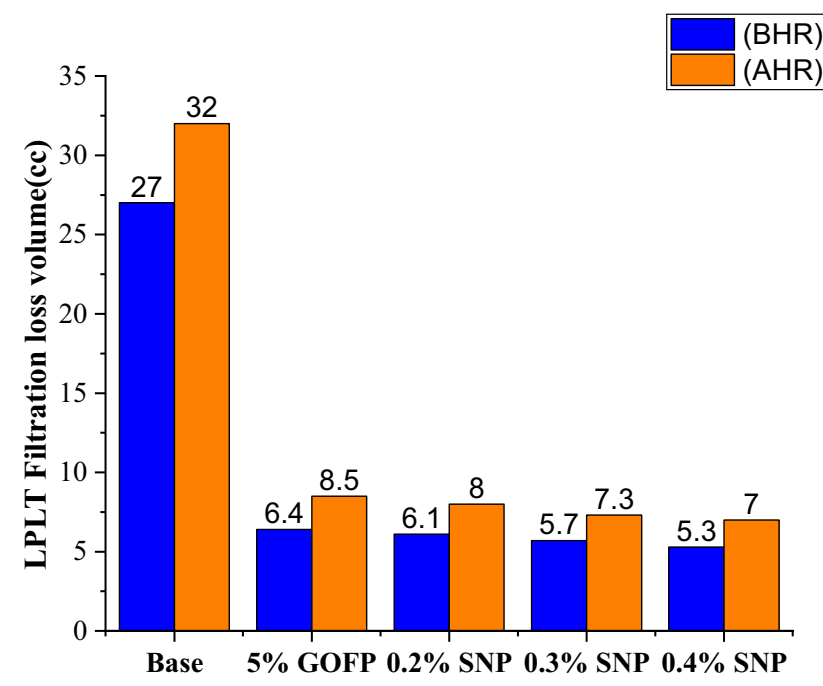

Fig. 10 Effect on LPLT filtration loss of different drilling fluid samples at BHR and AHR $\left(100{ }^{\circ} \mathrm{C}\right)$

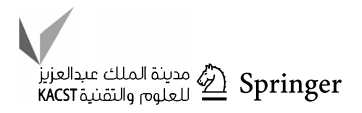




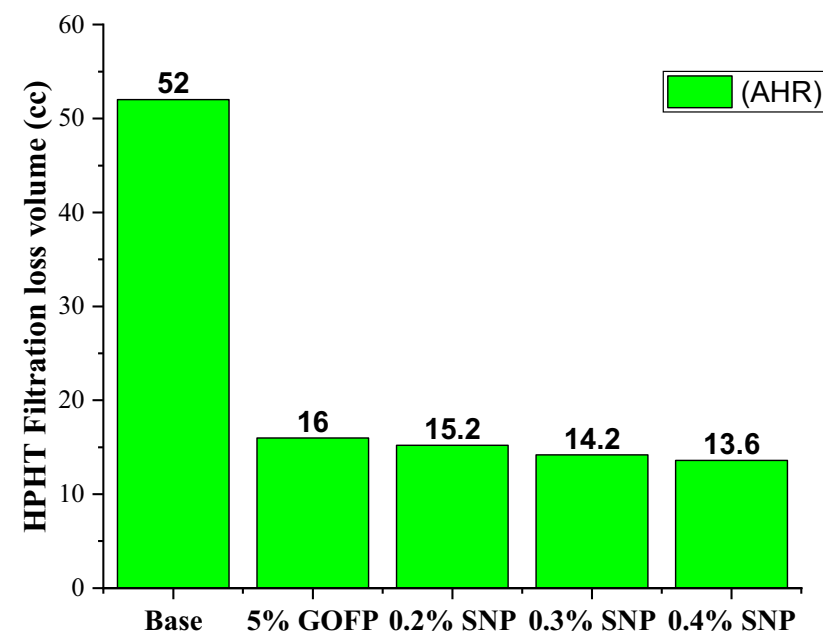

Fig. 11 a SEM image of filter cake obtained from base mud, b SEM image of the filter cake obtained from 5\% GOFP, c SEM image of the filter cake obtained from $5 \% \mathrm{GOFP}+0.4 \% \mathrm{SNP}$ at $1000 \mathrm{KX}$ magnification d SEM image of 5\% GOFP $+0.4 \%$ SNP at $25 \mathrm{KX}$ magnification showing effective plugging in filter paper

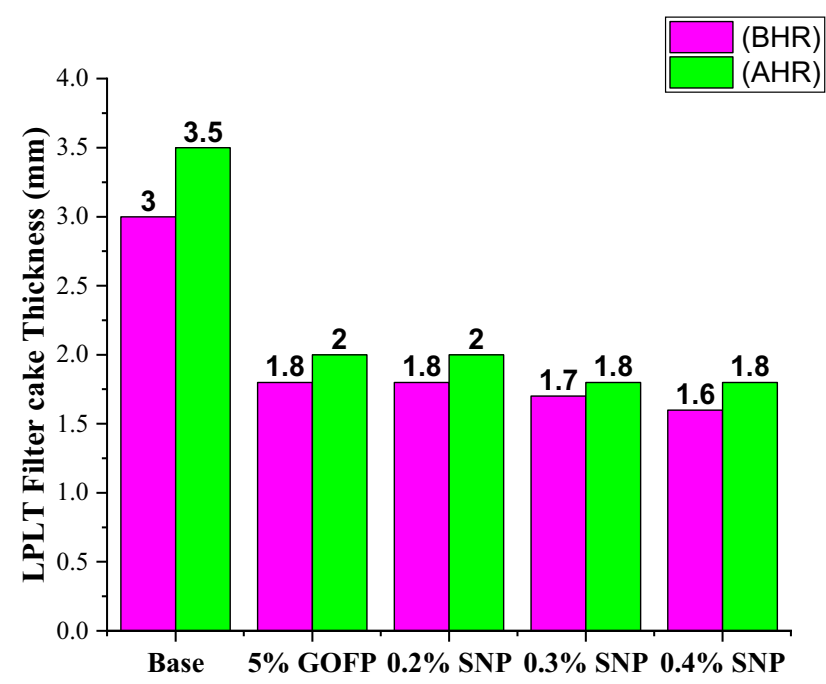

Fig. 12 Effect on LPLT filter cake thickness of different drilling fluid samples at BHR and $\mathrm{AHR}\left(100{ }^{\circ} \mathrm{C}\right)$

(from 47 to $17.5 \mathrm{ml}$ ), while at the same concentration of PAC, the LPLT filtration loss volume of drilling mud was reduced by $59.57 \%$ (from 47 to $19 \mathrm{ml}$ ). These data are suggested that GOFP at $5 \%$ concentration is highly cost effective and better filtration control agent in water-based drilling fluid. The filtration loos property of GOFP was improved by the addition of silica nano particles (ranging from 0.2 to $0.4 \%$ ) in the GOFP based mud. As per experimental results, it was observed that after the addition of SNP, the filtration control ability of GOFP was significantly increased. The LPLT filtration loss of drilling mud was decreased by $6.25 \%$ (from 8.5 to $8.0 \mathrm{ml}$ ), $14.1 \%$ (from 8.5 to $7.3 \mathrm{ml}$ ) and $17.6 \%$ (from 8.5 to $7.0 \mathrm{ml}$ ) with addition of $0.2,0.3$ and $0.4 \%$ SNP, respectively, in the GOFP mud. This filtration loss reduction indicates that SNP introduced the cross linking among the mud particles which made filter cake impermeable and improved its mightiness. As per Boyou et al. (2019), nanosilica introduced a wide range of particles size distribution in the mud and increased colloidal interactions. SEM study was also carried out on the filter cake obtained from the different mud systems, which is predicting the cross-linking ability of silica nano particle in drilling mud (Fig. 11c). Figure 12 shows that after hot rolling of mud samples at $100{ }^{\circ} \mathrm{C}$, $5 \%$ GOFP have reduced the filter cake thickness by $42.8 \%$ as compared to base mud (from 3.5 to $2.0 \mathrm{~mm}$ ). While the thickness of the filter cake formed by $0.4 \%$ SNP along with $5 \%$ GOFP was reduced by $48.5 \%$ as compared to base mud (from 3.5 to $1.8 \mathrm{~mm}$ ).

\section{HPHT filtration property}

Drilling fluid provide a hydrostatic pressure which should be greater than formation pressure or pore pressure to prevent the any unwanted flow from the wellbore (Bourgoyne et al. 1986; Stroud, 1922, 1926). The difference between the hydrostatic pressure and formation pressure is called overbalanced pressure. Since the recommended maximum overbalance pressure range between the formation pressure and hydrostatic pressure is 500 Psi (Rabia, 2002; Hossain and Al-Majed, 2015). Therefore, HTHP filtration test was conducted at $100{ }^{\circ} \mathrm{C}$ temperature under the differential pressure of 500 psi for 30 min. Experimental data plotted in Fig. 13 indicate that the after hot rolling of mud samples, the HPHT filtration loss volume of base mud was $52 \mathrm{ml}$ while it was reduced from 52 to $16 \mathrm{ml}$ by the addition of 5\% GOPF in the base mud. It was observed that the HPHT filtration loss control ability of GOFP was increased by the addition silica nano particles (SNP) in the drilling fluid. Due to the smaller size and larger surface area of silica nano particles, they effectively reduced the invasion of water into shale and control filtration loss of drilling fluid (Fakoya and Shah, 2017).

After the addition of $0.2,0.3$ and $0.4 \%$ concentration of SNP, the HPHT filtration loss of GOFP was reduced by $5 \%$ (from 16 to $15.2 \mathrm{ml}$ ), $11.25 \%$ (from 16 to $14.2 \mathrm{ml}$ ) and $15 \%$ (from 16 to $13.6 \mathrm{ml}$ ), respectively, at $100{ }^{\circ} \mathrm{C}$ and $500 \mathrm{psi}$ pressure. However, at optimum concentration of $0.4 \%$ SNP, the HPHT filtration loss volume of drilling mud was reduced by $73.84 \%$ (from 52 to $13.6 \mathrm{ml}$ ) as compared to base mud. This is due to high thermal stability of silica nano particles. However, in the absence of silica nano particle, the HPHT filtration loss volume of 5\% GOFP base mud was reduced by $69.2 \%$ (from 52 to $16 \mathrm{ml}$ ) as compared to base mud. Results revealed that silica nano particles in the drilling fluid provided the thermal stability to the drilling fluid and form an 

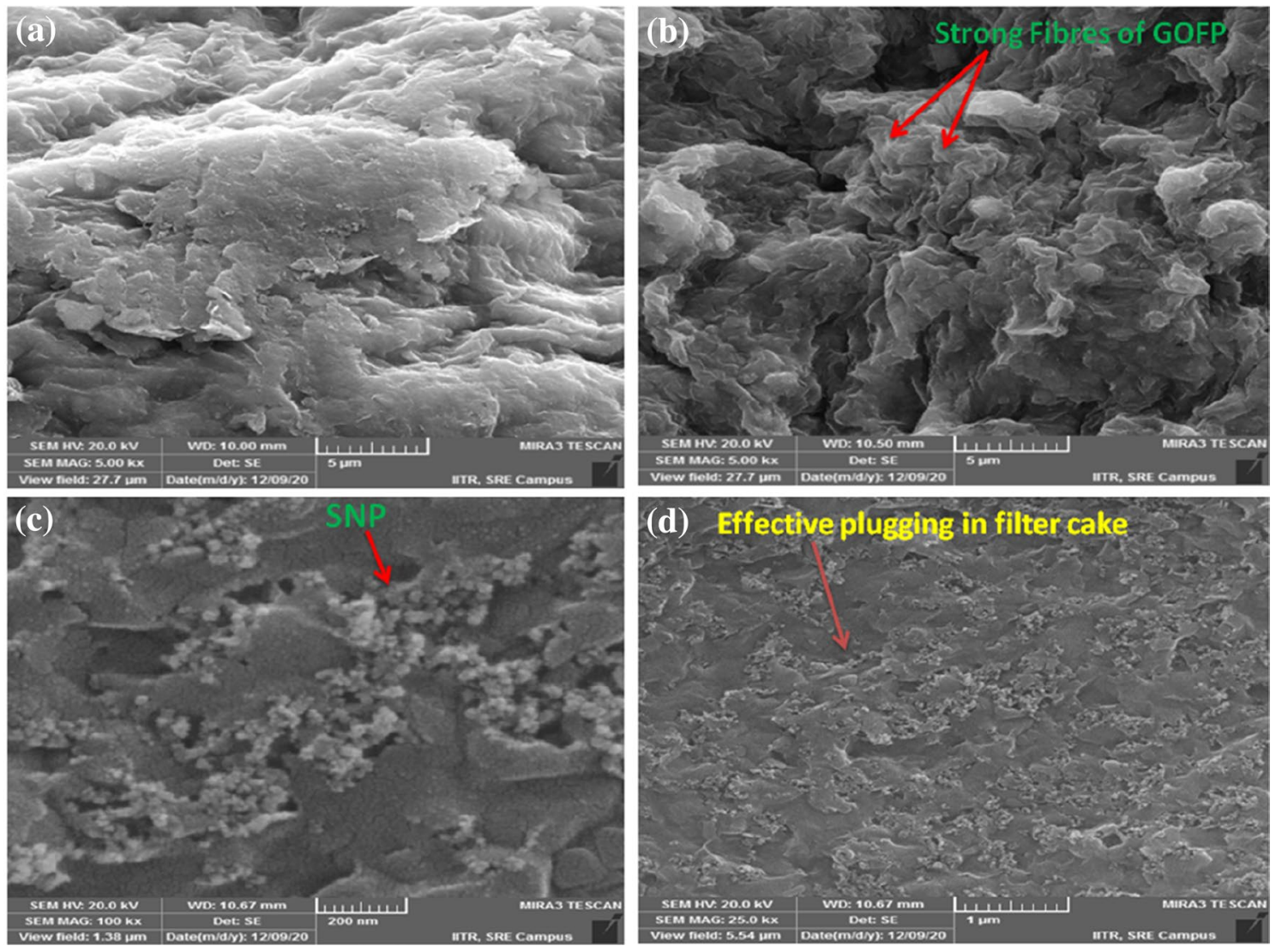

Fig. 13 Effect on HPHT filtration loss of different drilling fluid samples at BHR and AHR $\left(100{ }^{\circ} \mathrm{C}\right)$

impermeable bridge over the filter cake which reduced the filtration loss volume of the mud. Thus, in the deeper wells, $0.4 \%$ SNP is very effective to improve the HTHP filtration property of grewia optiva fibre during the drilling operations. This fluid loss reduction capability of SNP additive in drilling fluid may be mitigated different drilling problems like stuck up, shale hydration, tight pull, held up, well bore instability, etc. occurs during the drilling operation.

Recently, various studies have been done for improving the HPHT filtration property of WBM. Amanullah and Ramasamy, 2016) have used Date seed powder in waterbased mud. The study of this research revealed that $6 \mathrm{gm}$ date seed powder in $350 \mathrm{ml}$ base mud has reduced the HPHT filtration loss volume by $59.4 \%$ as compared to base mud. Gbadamosi et al. 2019 have investigated that after the addition of $0.5 \%(\mathrm{w} / \mathrm{v})$ silica nano particles in water-based mud, the HPHT filtration loss of drilling mud was reduced by $48 \%$ as compared to the base mud. Barry et al. 2015 used nano particle (3-30 nm size) in WBM. The HPHT filtration loss was reduced by $37 \%$ after the addition of $0.5 \%(\mathrm{w} / \mathrm{v})$ $\mathrm{Fe} 2 \mathrm{O} 3$ nano particles in the base mud. After long hot rolling of mud samples at 93 and $121{ }^{\circ} \mathrm{C}$ for $16 \mathrm{~h}, 0.5 \%(\mathrm{w} / \mathrm{v}) \mathrm{TiO} 2$ nano particles (particle size $250 \mathrm{~nm}$ ) have reduced he HPHT filtration loss of WBM by $58 \%$ and $39.9 \%$, respectively, as compared to base mud (Beg et al. 2020). However, in the current study, $0.4 \%(\mathrm{w} / \mathrm{v})$ silica nano particles $(30-50 \mathrm{~nm}$ size) with 5\% (w/v) GOFP have reduced the HPHT filtration loss of drilling mud by $73.84 \%$, which make the mixture of $0.4 \%$ SNP and 5\% GOFP more effective for designing of suitable drilling fluid. The thin and compact mud cake helps in decimating differential pipe sticking problems. The thickness of HPHT filter cake generated by base mud was $7.7 \mathrm{~mm}$, while after the addition of $0.4 \%$ SNP and 5\% GOFP in the base mud, the filter cake thickness was gradually decreased by $35.06 \%$ (from 7.7 to $5.0 \mathrm{~mm}$ ) and $45.4 \%$ (from 7.7 to $4.2 \mathrm{~mm}$ ), respectively, as compared to base mud (Table 3).

\section{Scanning electron microscopy (SEM) characterization of filter cake}

Scanning electron microscopy (SEM) was used to study the structure and the morphology of the filter cake. The SEM image was taken from the cross section of filter cake. This technique was used in this work to examine the effect of the different mud additives such as GOFP, silica nano particle $\left(\mathrm{SiO}_{2}\right)$, bentonite, etc. in the static filter cake formed during the fluid loss in WBM. The filter cake obtained from the 
base mud, i.e., bentonite (Fig. 11a) was appearing like the compact, smooth and homogenous clay soil surface with the particle size less than $5 \mu \mathrm{m}$. Figure $13 \mathrm{~b}$ is showing particle size less than $5 \mu \mathrm{m}$ of GOFP mud at $500 \mathrm{kx}$ magnification, which is showing the strong fibre of GOFP on the surface of the cake. While Fig. 13c is showing particles size less than $200 \mathrm{~nm}$ at100 KX magnification image of the SNP with GOFP additive in the filter cake. Due to the very smaller size and larger surface area of nano particles, they were found to be discretely dispersed throughout the filter cake and helped in bridging the micro sized gaps. Fig. 13d is indicating the effective plugging of pores of filter cake, after the addition of SNP in GOFP base mud. This effective plugging made an impermeable bridge over the filter cake and reduced the filtration loss volume of drilling mud.

\section{Permeability of the filter cake}

Among the various functions of the drilling mud, the most desired application is the minimum fluid loss volume by forming a low-permeable mud cake across the wall of the borehole. Drilling fluid with excessive filtration loss may influence the property of the well such as wellbore stability, differential sticking, and core recovery process, loss in mud volume and formation damage. Hence, an efficient drilling fluid is one which minimizes the filtrate loss in the formation by forming a thin filter cake with low permeability (Aston et al. 2002).

The permeability of filter cake is determined by Eq. (5) (Lomba, 2010):

$K=Q_{\mathrm{f}} \times \varepsilon \times \mu \times 8.95 \times 10^{-5}$

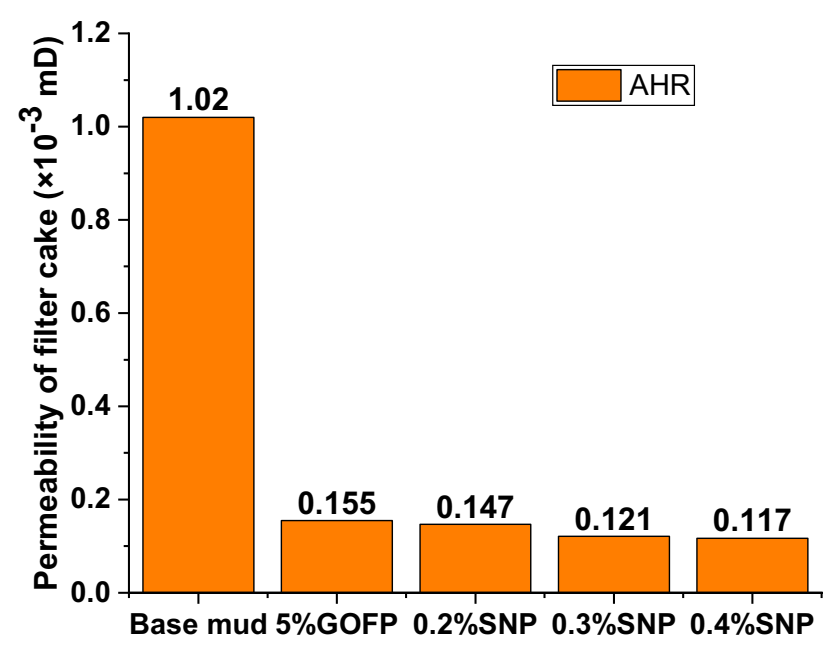

Fig. 14 Effect on the filter cake permeability of various drilling fluids AHR at $1000 \mathrm{C}$ for $16 \mathrm{~h}$
Table 4 Cake permeability for water-based mud formulated after hot rolling of mud samples at $100{ }^{\circ} \mathrm{C}$

\begin{tabular}{ll}
\hline Concentration & $\begin{array}{l}\text { Filter cake } \\
\text { permeability } \\
(\mathrm{mD})\end{array}$ \\
\hline Base mud & $1.02 \times 10^{-3}$ \\
$5 \% \mathrm{GOFP}$ & $0.155 \times 10^{-3}$ \\
$5 \% \mathrm{GOFP}+0.2 \% \mathrm{SNP}$ & $0.147 \times 10^{-3}$ \\
$5 \% \mathrm{GOFP}+0.3 \% \mathrm{SNP}$ & $0.121 \times 10^{-3}$ \\
$5 \% \mathrm{GOFP}+0.4 \% \mathrm{SNP}$ & $0.117 \times 10^{-3}$ \\
\hline
\end{tabular}

, where $\mathrm{K}=$ permeability of mud cake $(\mathrm{mD}) . \boldsymbol{\varepsilon}=$ thickness of mud cake (mm). $\mu=$ Viscosity of fluid in (cp).

After log hot rolling of drilling mud, the force of attraction among the particles are decomposed due to the effect of temperature. Therefore, permeability of filter cake obtained from the different drilling mud was measured after long hot rolling of mud samples at $100^{\circ} \mathrm{C}$ for $16 \mathrm{~h}$. The permeability of various filter cake obtained after the LPLT filtration loss of drilling fluids are shown in Table 4. After the addition of $5 \%$ GOFP in base mud, the permeability of filter cake was reduced from $1.02 \times 10^{-3}$ to $0.155 \times 10^{-3} \mathrm{mD}$ (Fig. 14). . However, after the addition of $5 \%$ GOFP $+0.4 \%$ SNP mixture in the base mud, the permeability of cake was drastically reduced from $1.02 \times 10^{-3}$ to $0.117 \times 10^{-3} \mathrm{mD}$. This plugging tendency of SNP-GOFP mixture in the drilling mud would be reduced the invasion of any solid and liquid particle into the permeable formations during the drilling operation.

\section{Cost analysis}

Grewia optiva fibre is an agro plant and easily available in nature. It is more cost effective and environment friendly than the conventional fluid loss control additives, e.g., CMCLVG and PAC-LVG. The cost of different fluid loss control (Table 5).

\section{Conclusion}

As per experimental studies, it was observed that the filtration loss and rheological properties of GOFP additives was effectively improved by using silica nano particles in the water-based drilling fluid. After hot rolling of mud samples

Table 5 Cost of fluid loss control material

\begin{tabular}{lll}
\hline Material & Cost/kg (USD) & Source \\
\hline Carboxy methyl cellulose & 4.96 & Okoro et al. (2018) \\
Poly anionic cellulose & 6.0 & Okoro et al. (2018) \\
Grewia optiva fibre & 0.3 (Approximately) & Shishir (2016) \\
\hline
\end{tabular}


at $100{ }^{\circ} \mathrm{C}$ for $16 \mathrm{~h}, 0.4 \%$ (optimum concentration) of SNP have reduced the LPLT and HPHT filtration loss of GOFP additive by $17.6 \%$ (from 8.5 to $7.0 \mathrm{ml}$ ) and $15 \%$ (from 16 to $13.6 \mathrm{ml}$ ), respectively, in WBM. However, the mixture of $0.4 \% \mathrm{SNP}+5 \%$ GOFP-based mud has reduced the LPLT and HPHT filtration loss by 78.1 and $74.03 \%$ respectively as compared to base mud. The LPLT and HPHT filtration control ability of GOFP additive were increased by 17.6 and $15 \%$, respectively, by using SNP in WBM. This reduction in filtration loss would be mitigated the various wellbore instability problems in high temperature and high pressure wells. Thickness of LPLT and HPHT filter cake produced by the mixture of $0.4 \% \mathrm{SNP}+5 \%$ GOFP based mud was reduced by 48.5 and $45.4 \%$ respectively with respect to base mud. Reduction in the thickness of filter cake would be prevented of string stuck up problems. The YP of $0.4 \% \mathrm{SNP}+5 \%$ GOFP mixture mud was increased by $87.5 \%$, as compared to base mud. While the YP of drilling mud containing GOFP was increased by $23.3 \%$ after the addition of $0.4 \%$ SNP on it. The $0.4 \% \mathrm{SNP}+5 \% \mathrm{GOFP}$ mixture has also increased the Gel 0 and Gel 10 of drilling mud by 21 and $36 \%$ respectively as compared to base mud.

Acknowledgements Authors are thankful to IDT, ONGC (Oil and Natural Gas Corporation Ltd.), Dehradun, Uttarakhand, India, for support in the research and also thankful to Indian Institute of Technology (IIT), Rookree, India for SEM and XRD studies, and Rajiv Gandhi institute of Petroleum Technology for analysis of Zeta Potential and particle size analysis.

Funding No funding was secured for this manuscript.

\section{Declarations}

Conflict of interest On behalf of all authors, the corresponding author states that there is no conflicts of interest.

Open Access This article is licensed under a Creative Commons Attribution 4.0 International License, which permits use, sharing, adaptation, distribution and reproduction in any medium or format, as long as you give appropriate credit to the original author(s) and the source, provide a link to the Creative Commons licence, and indicate if changes were made. The images or other third party material in this article are included in the article's Creative Commons licence, unless indicated otherwise in a credit line to the material. If material is not included in the article's Creative Commons licence and your intended use is not permitted by statutory regulation or exceeds the permitted use, you will need to obtain permission directly from the copyright holder. To view a copy of this licence, visit http://creativecommons.org/licenses/by/4.0/.

\section{References}

Abbas AK, Alsaba MT, Al Dushaishi MF (2021) Improving hole cleaning in horizontal wells by using nanocomposite water-based mud. J Petrol Sci Eng 203:108619. https://doi.org/10.1016/j.petrol. 2021.108619
Adebowale, A., Raji, J. (2015) Local content supplements as an alternative to imported corrosion control additive for drilling mud treatment (A Case Study of the Use of Burnt Plantain and Banana Peels). In: proceedings of the international academic conference for sub-sahara African transformation and development Vol. 3 No.4 University of Ilorin, 1000 Capacity Lecture Theatre Hall, Ilorin, Kwara State Nigeria.

Aftab A, Ismail AR, Ibupoto ZH, Akeiber H, Malghani MGK (2017) Nanoparticles based drilling muds a solution to drill elevated temperature wells: a review. Renew Sustain Energy Rev 76:13011313. https://doi.org/10.1016/j.rser.2017.03.050

Agwu OE, Akpabio JU, Archibong GW (2019) Rice husk and saw dust as filter loss control agents for water-based muds. Heliyon 5(7):e02059. https://doi.org/10.1016/j.heliyon.2019.e02059

Akhtarmanesh S, Shahrabi MJA, Atashnezhad A (2013) Improvement of wellbore stability in shale using nanoparticles. J Petrol Sci Eng 112:290-295. https://doi.org/10.1016/j.petrol.2013.11.017

Al-Hameedi and T. T., Alkinani, H. H., Dunn-Norman, S., Alashwak, N. A., Alshammari, A. F., Alkhamis, M. M., Alsaba, M. T. , 2019 A Al-Hameedi T. T., Alkinani, H. H., Dunn-Norman, S., Alashwak, N. A., Alshammari, A. F., Alkhamis, M. M., Alsaba, M. T. (2019) Environmental friendly drilling fluid additives: Can food waste products be used as thinners and fluid loss control agents for drilling fluid? In: society of petroleum engineers - SPE symposium: asia pacific health, safety, security, environment and social responsibility. Society of Petroleum Engineers https://doi.org/10. 2118/195410-ms

Alsaba, M., Nygaard, R., Hareland, G. (2014). Review of lost circulation materials and treatments with an updated classification. In: AADE national technical conference and exhibition, Houston, TX, Apr, pp. 15e16.

Al-Yasiri M, Awad A, Pervaiz S, Wen D (2019) Influence of silica nanoparticles on the functionality of water-based drilling fluids. J Petrol Sci Eng 179:504-512. https://doi.org/10.1016/j.petrol. 2019.04.081

Amanullah M, Ramasamy J, Al-Arfaj MK (2016) Application of an indigenous eco-friendly raw material as fluid loss additive. J Petrol Sci Eng 139:191-197. https://doi.org/10.1016/j.petrol.2015. 12.023

American Petroleum Institute. Third ed. American Petroleum Institute; (2003). Recommended practice for field testing of water based drilling fluids (API 13B-1).

Aramendiz J, Imqam A (2019) Water-based drilling fluid formulation using silica and graphene nanoparticles for unconventional shale applications. J Petrol Sci Eng 179:742-749. https://doi.org/10. 1016/j.petrol.2019.04.085

Aston M, Mihalik P, Tunbridge J, Clarke S (2002) Towards zero fluid loss oil referenced mud. Society of Petroleum Engineers, SPE Paper, $\mathrm{p} 77446$

Baker H (2006) Drilling Fluids reference manual. Baker Hughes Drilling Fluid, Houston, TX

Barry MM, Jung Y, Lee JK, Phuoc TX (2015) Fluid filtration and rheological properties of nanoparticle additive and intercalated clay hybrid bentonite drilling fluids. J Petrol Sci Eng 127:338-346

Bayat AE, Shams R (2019) Appraising the impacts of $\mathrm{SiO} 2, \mathrm{ZnO}$ and $\mathrm{TiO} 2$ nanoparticles on rheological properties and shale inhibition of water-based drilling muds. Colloids Surfaces A Physicochem Eng Asp 581:1237. https://doi.org/10.1016/j.colsurfa.2019. 123792

Beg M, Kumar P, Choudhary P, Sharma S (2020) Effect of high temperature ageing on $\mathrm{TiO} 2$ nanoparticles enhanced drilling fluids: a rheological and filtration study. Upstream Oil Gas Technol 5:100019. https://doi.org/10.1016/j.upstre.2020.100019

Beg, M., Kesarwani, H., Sharma, S. (2019). Effect of $\mathrm{CuO}$ and $\mathrm{ZnO}$ nanoparticles on efficacy of poly 4-Styrenesulfonic Acid-Comaleic acid sodium salt for controlling HPHT filtration, In:

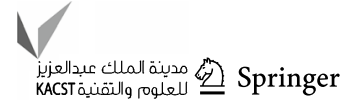


proceedings of the abu dhabi international petroleum exhibition and conference, SPE, Abu Dhabi, pp. 1-11, doi: https://doi.org/ 10.2118/197703-ms.

Bourgoyne., A.T. Jr., Chenevert., M.E., Millheim, Keith, K., Young, F.S. Jr., (1986). Applied drilling engineering.

Boyou NV, Ismail I, Wan Sulaiman WR, Sharifi Haddad A, Husein N, Hui HT, Nadaraja K (2019) Experimental investigation of hole cleaning in directional drilling by using nano-enhanced waterbased drilling fluids. J Petrol Sci Eng 176:220-231. https://doi. org/10.1016/j.petrol.2019.01.063

Caenn R, Darley HCH, Gray GR (2017) Drilling problems related to drilling fluids. Compos Prop Drill Compl Fluids. https://doi.org/ 10.1016/b978-0-12-804751-4.00010-9

Caenn R, Darley HCH, Gray GR (2017) The filtration proper- ties of drilling fluids. Compos Prop Drill Compl Fluids 245:283. https:// doi.org/10.1016/b978-0-12-804751-4.00007-9

Caenn R, Darley HCH, Gray GR (2017) The rheology of drilling fluids. Compos Prop Drill Compl Fluids 151:244. https://doi.org/10. 1016/b978-0-12-804751-4.00006-7

Caenn R, Darley HCH, Gray GR (2017) Introduction to drilling fluids. Compos Compos Prop Drill Compl Fluds. https://doi.org/10.1016/ b978-0-12-804751-4.00001-8

Caldarola, V. T., Akhtarmanesh, S., Cedola, A. E., Qader, R., and Hareland, G. (2016). Potential directional drilling benefits of barite nanoparticles in weighted water based drilling fluids. In: 50th US rock mechanics / geomechanics symposium 2016 (Vol. 3, pp. 1847-1851). American Rock Mechanics Association (ARMA).

Chaouf S, Barkany S, Jilal I, Ouardi Y, Abou-salama M, Loutou M, Houssaine El-A, Ouarghi El-H, El-A Idrissi H, Amhamdi (2019) Anionic reverse microemulsion grafting of acrylamide (AM) on HydroxyEthylCellulose (HEC): Synthesis, characterization and application as new ecofriendly low-cost flocculant. J Water Process Eng 31:100807. https://doi.org/10.1016/j.jwpe.2019.100807

Cheraghian G (2021) Nanoparticles in drilling fluid: A review of the state-of-the-art. J Market Res 13:737-753. https://doi.org/10. 1016/j.jmrt.2021.04.08

Cheraghian G, Wu Q, Mostofi M, Li MC, Afrand M, Sangwai JS (2018) Effect of a novel clay/silica nanocomposite on water-based drilling fluids: Improvements in rheological and filtration properties. Colloids Surf, A Physicochem Eng Asp 555:339-350. https:// doi.org/10.1016/j.colsurfa.2018.06.072

Davoodi AS, Ramazani SA, Soleimanian A, Fellah Jahromi A (2019) Application of a novel acrylamide copolymer containing highly hydrophobic comonomer as filtration control and rheology modifier additive in water-based drilling mud. J Pet Sci Eng 180:747755. https://doi.org/10.1016/j.petrol.2019.04.069

Dejtaradon P, Hamidi H, Chuks MH, Wilkinson D, Rafati R (2019) Impact of $\mathrm{ZnO}$ and $\mathrm{CuO}$ nanoparticles on the rheological and filtration properties of water-based drilling fluid. Colloids Surf A Physicochem Eng Asp 570:354-367. https://doi.org/10.1016/j. colsurfa.2019.03.050

Fakoya MF, Shah SN (2017) Emergence of nanotechnology in the oil and gas industry: emphasis on the application of silica nanoparticles. Petrol 3(4):391-405. https://doi.org/10.1016/j.petlm.2017. 03.001

Fatihah Majid NF, Katende A, Ismail I, Sagala F, Sharif NM, Che Yunus MA (2019) A comprehensive investigation on the performance of durian rind as a lost circulation material in water based drilling mud. Petroleum 5(3):285-294. https://doi.org/10.1016/j. petlm.2018.10.004

Fink, J.K. (2012).Petroleum engineer's guide to oil field chemicals and fluids. Gulf Profess. Pub.

Gaur R (1999) Flora of the district garhwal north west Himalaya, trans media. Srinagar (garhwal) 1:150
Gbadamosi AO, Junin R, Abdalla Y, Agi A, Oseh JO (2019) Experimental investigation of the effects of silica nanoparticle on hole cleaning efficiency of water-based drilling mud. J Petrol Sci Eng 172:1226-1234. https://doi.org/10.1016/j.petrol.2018.09.097

Ghazali NA, Mohd TAT, Alias NH, Azizi A, Harun AA (2014) The effect of lemongrass as lost circulation material (LCM) to the filtrate and filter cake formation. Key Eng Mater 594-595:68-72

Hakim H, Katende A, Sagala F, Ismail I, Nsamba H (2018) Performance of polyethylene and polypropylene beads towards drill cuttings transportation in horizontal wellbore. J Petrol Sci Eng 165:962-969. https://doi.org/10.1016/j.petrol.2018.01.075

Hoelscher, K. P., De Stefano, G., Riley, M., and Young, S. (2012). Application of nanotechnology in drilling fluids. In: 2012 society of petroleum engineers - spe international oilfield nanotechnology conference pp 297-303. https://doi.org/10.2118/157031-ms

Hossain M, Al-Majed AA (2015) Fundamentals of sustainable drilling engineering. Wiley

Hossain ME, Wajheeuddin M (2016) The use of grass as an environmentally friendly additive in water-based drilling fluids. Pet Sci 13(2):292-303. https://doi.org/10.1007/s12182-016-0083-8

Iranwan S, Azmi A, Saaid M (2009) Corn cobs and sugar cane waste as viscosifier in drilling fluid. Pertanika J Sci Technol 17(173):181

Jain R, Mahto V (2015) Evaluation of polyacrylamide/clay composite as a potential drilling fluid additive in inhibitive water based drilling fluid system. J Pet Sci Eng 133:612-621. https://doi.org/10. 1016/j.petrol.2015.07.009

Kafashi S, Rasaei M, Karimi G (2017) Effects of sugarcane and polyanionic cellulose on rheological properties of drilling mud: an experimental approach. Egypt J Pet 26(371):374. https://doi.org/ 10.1016/j.ejpe.2016.05.009

Karakoti A, Ronald J, Dasan Priya K, Rajesh M (2020) Micro cellulose grewia optiva fibre-reinforced polymer composites: relationship between structural and mechanical properties. J Nat Fibres. https:// doi.org/10.1080/15440478.2020.1800549

Katende A, Boyou NV, Ismail I, Chung DZ, Sagala F, Hussein N, Ismail MS (2019) Improving the performance of oil based mud and water based mud in a high temperature hole using nanosilica nanoparticles. Colloids Surf A: Physicochem Eng Aspects. 577:645-673. https://doi.org/10.1016/j.colsurfa.2019.05.088

Li MC, Wu Q, Song K, Qing Y, Wu Y (2015) Cellulose nanoparticles as modifiers for rheology and fluid loss in bentonite water-based fluids. ACS Appl Mater Interfaces 7(8):5009-5016. https://doi. org/10.1021/acsami.5b00498

Li MC, Tang Z, Liu C, Huang R, Koo MS, Zhou G, Wu Q (2020a) Water-redispersible cellulose nanofiber and polyanionic cellulose hybrids for high-performance water-based drilling fluids. Ind Eng Chem Res 59(32):14352-14363. https://doi.org/10.1021/acs.iecr. 0c02644

Li MC, Wu Q, Han J, Mei C, Lei T, Lee SY, Gwon J (2020b) Overcoming salt contamination of bentonite water-based drilling fluids with blended dual-functionalized cellulose nanocrystals. ACS Sustain Chem Eng 8(31):11569-11578. https://doi.org/10.1021/ acssuschemeng.0c02774

Li MC, Wu Q, Lei T, Mei C, Xu X, Lee S, Gwon J (2020c) Thermothickening drilling fluids containing bentonite and dual-functionalized cellulose nanocrystals. Energy Fuels 34(7):8206-8215. https://doi.org/10.1021/acs.energyfuels.0c01192

Lian X, Su Z, Yuan Y (2019) Study on the effect of the oil-water ratio on the rheological properties of hydroxyethyl cellulose (HEC). Geofluids. https://doi.org/10.1155/2019/7405702

Liu F, Jiang G, Peng S, Wang J (2016) Amphoteric polymer as an anticalcium contamination fluid-loss additive in water-based drilling fluids. Energy Fuels 30:7221-7228. https://doi.org/10.1021/acs. energyfuels.6b01567

Loggins, S. M. J., Cunningham, C., Akhtarmanesh, S., Gunter, B., and G. Hareland. (2017) The effect of mechanically and chemically 
generated barite nanoparticles on the reduction of fluid filtrate. Paper presented at the 51st U.S. rock mechanics/geomechanics symposium, San Francisco, California, USA.

Lomba., R.(2010). Fundamentos de filtração e controle das propriedades de filtração, Report. (in Portuguese).

Magzoub MI, Salehi S, Hussein I, Nasser M (2021) Development of a polyacrylamide-based mud formulation for loss circulation treatments. J Energy Res Technol, Trans ASME. https://doi.org/10. $1115 / 1.4048682$

Mao H, Qiu Z, Shen Z, Huang W (2015) Hydrophobic associated polymer based silica nanoparticles composite with core-shell structure as a filtrate reducer for drilling fluid at ultra-high temperature. J Petrol Sci Eng 129:1-14. https://doi.org/10.1016/j.petrol.2015. 03.003

Mech D, Sangwai JS (2016) Effect of molecular weight of polyethylene glycol (PEG), a hydrate inhibitive water-based drilling fluid additive, on the formation and dissociation kinetics of methane hydrate. J Nat Gas Sci Eng 35:1441-1452. https://doi.org/10. 1016/j.jngse.2016.06.020

Menezes RR, Marques LN, Campos LA, Ferreira HS, Santana LNL, Neves GA (2010) Use of statistical design to study the influence of CMC on the rheological properties of bentonite dispersions for water-based drilling fluids. Appl Clay Sci 49:13-20. https://doi. org/10.1016/j.clay.2010.03.013

Nyeche W, Nmegbu J, Ifeoma P (2015) Drilling mud formulation using potato starch (Ipomoea batatas). J Eng Res Appl 5:48-54

Okon AN, Udoh FD, Bassey PG (2014) Evaluation of rice husk as fluid loss control additives in water based drilling mud. Soc Petrol Eng. https://doi.org/10.2118/172379-MS

Okoro EE, Dosunmu A, Iyuke SE (2018) Data on cost analysis of drilling mud displacement during drilling operation. Data Brief 19:535-541. https://doi.org/10.1016/j.dib.2018.05.075

Omotioma M, Ejikeme PCN, Mbah GO (2014) Comparative analysis of the effects of cashew and mango extracts on the rheological properties of water based mud. J Eng Res Appl 4:56-61

Onuh CY, Igwilo KC, Anawe PAL, Olakunle D, Omotoke O (2017) Environmentally friendly fluid loss control agent in water-based mud for oil and gas drilling operations. Int J Appl Eng Res 12(8):1520-1523

Pakdaman E, Osfouri S, Azin R, Niknam K, Roohi A (2019) Improving the rheology, lubricity, and differential sticking properties of water-based drilling muds at high temperatures using hydrophilic Gilsonite nanoparticles. Colloids Surf A Physic-ochem. Eng. Asp. 582:123930. https://doi.org/10.1016/j.colsurfa.2019.123930

Perween S, Beg M, Shankar R, Sharma S, Ranjan A (2018) Effect of zinc titanate nano particles on rheological and filtration properties of water based drilling fluids. J Pet Sci Eng 170:844-857. https:// doi.org/10.1016/J.PETROL.2018.07.006

Perween S, Thakur NK, Beg M, Sharma S, Ranjan A (2019) Enhancing the properties of water based drilling fluid using bismuth ferrite nanoparticles. Colloids Surf A Physicochem Eng Asp 561:165177. https://doi.org/10.1016/J.COLSURFA.2018.10.060

Prakash V, Sharma N, Bhattacharya M (2020) Feasibility studies of the environment-friendly Grewia optiva fibers as an alternative to the conventional noninvasive fluid additive (NIFA) in water-based drilling fluid. Petroleum Sci Technol 39(5):133-151. https://doi. org/10.1080/10916466.2020.1844230

Rabia, H., (2002). Well Engineering and Construction. Entrac Consulting.
Rafati R, Smith SR, SharifiHaddad A, Novara R, Hamidi H (2018) Effect of nanoparticles on the modifications of drilling fluids properties: a review of recent advances. J Pet Sci Eng 161:61-76. https://doi.org/10.1016/j.petrol.2017.11.067

Sadeghalvaad M, Sabbaghi S (2015) The effect of the TiO2/polyacrylamide nanocomposite on water-based drilling fluid properties. Powder Technol 272:113-119. https://doi.org/10.1016/j.powtec. 2014.11.032

Segal L, Creely JJ, Martin AE, Conrad CM (1959) An empirical method for estimating the degree of Crystallinity of native cellulose using the X-ray diffractometer. Text Res J 29:786-794. https://doi.org/10.1177/004051755902901003

Selvarajan E, Mohanasrinivasan V (2013) Biosynthesis and characterization of $\mathrm{ZnO}$ nanoparticles using Lactobacillus plantarum VITES07. Mater Lett 112:180-182. https://doi.org/10.1016/j. matlet.2013.09.020

Shishir, P. (2016). An ingenious use of Fibre 2 Fashion. https://www.fibre2fashion.com/industry article/7732/ an-ingenious-use-of-fibres.

Stroud, B. K., (1922). Mud-laden fluids and tables on specific gravities and collapsing pressures. Louisiana Department of Conservation.

Stroud, B. K., (1926). Application of mud-laden fluids to oil or gas wells. US patent $1575945 \mathrm{~A}$.

Upreti B, Chaudhary AK (2017) Experimental study of mechanical properties of bhimal fiber reinforced epoxy bio-composite. Int J Innov Res Sci, Eng Technol 6(8):16926-16931. https://doi.org/ 10.15680/IJIRSET.2016.0608176

Villada Y, Gallardo F, Erdmann E, Casis N, Olivares L, Estenoz D (2017) Functional characterization on colloidal suspensions containing xanthan gum (XGD) and polyanionic cellulose (PAC) used in drilling fluids for a shale formation. Appl Clay Sci 149:59-66. https://doi.org/10.1016/j.clay.2017.08.020

Wang K, Jiang G, Liu F, Yang L, Wang X, Ni J (2018) Magnesium aluminum silicate nanoparticles as a high-performance rheological modifier in water-based drilling fluids. Appl Clay Sci 161:427435. https://doi.org/10.1016/j.clay.2018.05.012

Yi TT, Ismail I, Katende A, Sagala F, Mugisa M (2017) Experimental investigation of cuttings lifting efficiency using low and high density polyethylene beads in different hole angles. J Mater Sci Appl 3:71-78

Zakaria MF, Husein M, Hareland G (2012) Novel nanoparticle-based drilling fluid with improved characteristics. In: 2012 society of petroleum engineers SPE international oilfield nanotechnology conference, pp 232-237. https://doi.org/10.2118/1112-0100-jpt

Zhang L, Sun H, Han B, Peng L, Ning F, Jiang G, Chehotkin VF (2016) Effect of shearing actions on the rheological properties and mesostructures of CMC, PVP and CMC + PVP aqueous solutions as simple water-based drilling fluids for gas hydrate drilling. J Unconv Oil Gas Resour 14:86-98. https://doi.org/10.1016/j.juogr. 2016.02.002

Zhang L, Wu X, Sun Y, Cai J, Lyu S (2020) Experimental study of the pomelo peel powder as novel shale inhibitor in water-based drilling fluids. Energy Explor Exploit 38(2):569-588. https://doi.org/ $10.1177 / 0144598719882147$

Publisher's Note Springer Nature remains neutral with regard to jurisdictional claims in published maps and institutional affiliations. 